\title{
Sources and Management of Sustainable Waste
}

Case Study: Sultan Hasanuddin International Airport Makassar South Sulawesi Indonesia

\author{
Natsir Abduh \\ Bosowa University-Makassar in Indonesia \\ Department of Civil Engineering \\ abduhnatsir@gmail.com
}

\begin{abstract}
The research aims to find out the source of garbage from various object activities and find out the waste management system at Sultan Hasanuddin International Airport, Makassar South Sulawesi Indonesia. The study was conducted in September 2015 at Sultan Hasanuddin International Airport in Makassar, South Sulawesi through a survey in the form of interviews, direct observation. Taking and measuring samples at places where there are human activities and points that are considered to represent samples, such as in public services. The focus of research is on the Land Side of the Airport based on the SNI 19-3964-1994 method. which is used in this research is a quantitative approach by calculating the weight and volume of waste generation from each sample point. Of the ten samples observed, the waste generation was obtained at; check in area $74.8 \mathrm{Itr}$, departure area $20.06 \mathrm{Itr}$, arrival area $46.8 \mathrm{Itr}$, public service $96.6 \mathrm{Itr}$, service office $2.42 \mathrm{Itr}$, luaggage $52.4 \mathrm{ltr}$, cargo $208 \mathrm{ltr}$, minimarket / café $87.3 \mathrm{ltr}$, restaurant $155.3 \mathrm{Itr}$ and vehicle parking $231.4 \mathrm{Itr}$. The waste management system is carried out through the 3R method; namely Reduce: $27.29 \%$ waste management, Reuse: $36.37 \%$ waste management, Recycle: $33.7 \%$ waste management and the remaining $2.64 \%$ waste is disposed of to landfills.
\end{abstract}

\section{Introduction}

Waste is waste material both from animals, humans, and plants that are no longer used and disposed of into the environment in the form of solids, liquids or gases. Waste is one of the main problems in the world, such as in Indonesia which requires good management. Waste is waste material that is discarded because the material is considered to be worthless, does not have economic value so it is disposed of into the environment and because of its nature, concentration and / or volume, it requires special management (Natsir Abduh, 2016).

In the Law of the Republic of Indonesia No. 18 of 2008, it was said that waste problems cover many aspects, therefore management must be carried out comprehensively and integratedly. New, more adequate innovations are needed in terms of all aspects; such as social aspects, economic aspects and technical aspects from upstream to downstream in order to provide economic benefits, be healthy for the environment, and can change people's behavior.

The airport is the gateway of a country that becomes access to various political, socio-cultural, economic and tourism aspects. Besides that airports also help a lot in the economic and social development of the 
Natsir Abduh; Sources and Management of Sustainable Waste. Case Study: Sultan Hasanuddin International Airport Makassar South Sulawesi Indonesia. Journal of Biomedical Engineering and Medical Imaging, Volume 5, No 6, December (2018), pp 10-17

surrounding community, but on the other hand the operation has a negative impact. Activities at airports produce waste in the form of waste containing materials that are harmful to humans. Waste thrown into the environment can reduce environmental quality. If this situation continues without regard to natural capabilities, the concept of sustainability will not be achieved (Natsir Abduh, 2016).

Waste materials at the airport are sourced from passengers, visitors, crew, airport staff, cleaning plants, commercial activities, aircraft maintenance and building maintenance. Activities at the airport will increase the amount of solid waste, most of which is domestic waste and Hazardous Toxic Material. Hazardous Toxic Material in the form of waste comes from aircraft maintenance, such as used oil that is wasted around aircraft hangars (Adisasmita and Hadipramana, 2011). Airport operation is required for an environmental quality control system to be a high priority, such as noise, air quality, waste management, waste management, and environmentally friendly activities (Natsir Abduh, 2016).

Waste management at Sultan Hasanuddin International Airport needs to be done effectively and efficiently by taking into account the functional elements of waste management. Waste is obtained in the form of food scraps, plastic, paper, cans and trash remnants on the yard. The biggest composition of the waste source that most generates waste generation is paper (Leony Yermina A, Mery Salintung and Irwan Ridwan R, 2014).

One of the concepts of Environmental Sustainability Management can be done using the 3R method. This method is in the form of; Reuse, which is the reuse of an item that is not used for other purposes, without the need to experience a production process. Reduse, which is reducing waste production. Recycle, which is reprocessing the waste produced into other goods with higher value (Pranata Dedy, 2014).

Community-based waste management with the $3 R$ concept aims to reduce waste starting from its source, reduce environmental pollution, provide benefits to the community, and can change people's behavior towards waste. The $3 \mathrm{R}$ concept is actually very simple and easy to implement, but it is difficult to implement because the success of the $3 R$ concept is largely determined by people's participation by changing their behavior which is generally influenced by the socio-cultural character and socio-economic character. The changing paradigm of the community in waste management must start now (Natsir Abduh, 2015).

The application of the $3 R$ concept in managing waste in a self-managed manner by the community by changing the behavior of "throwing" garbage into "managing" garbage is one of the sustainable concepts. Sustainable development that is environmentally sound is a conscious and planned effort that integrates the environment, including resources into the development process to ensure the ability, welfare and quality of life of present and future generations. This concept states that sustainable development meets the needs of the present without having to reduce the ability to meet the needs of future generations. Sustainable development must pay attention to environmental use and environmental sustainability so that the quality of the environment is maintained, so that the carrying capacity of the environment is not reduced or lost. The meaning of sustainable development is that social justice from generation to generation has been achieved (Dorodjatun, K., 2011). 
This research was conducted in September 2015 and aims to find out the source of garbage from various object activities and find out the waste management system at Sultan Hasanuddin International Airport, Makassar South Sulawesi.

\section{Research Method}

The research was conducted through a survey in the form of interviews, direct observation of the waste management system, retrieval and measurement of generation samples and the composition of waste using the SNI 19-3964-1994 method. The collection of garbage samples from several points considered to represent activities at the airport, including parking of vehicles, passenger terminals and aircraft hangars. The focus of research is on the Airport Side, so that the sample points are in that area.

Pendekatan yang digunakan dalam penelitian ini adalah pendekatan kuantitatif melalui perhitungan berat dan volume timbulan sampah dari masing-masing titik sampel. Waste samples are collected, separated according to their type or composition. The sample is weighed and then put into a measuring vessel provided with a size $(20 \times 20 \times 100) \mathrm{cm}$ and compacted. The volume of waste is obtained by knowing the height of the waste in the measuring vessel.

The data obtained is studied and analyzed in depth on the sources and amount of waste generated and the waste management system. Survey data is the basis of planning in the waste management system carried out at Sultan Hasanuddin International Airport.

\section{Research Result}

\subsection{Waste Source}

Garbage is a problem in every city, including in Indonesia, which eventually accumulates in the Final Disposal Site. Garbage comes from the terminal building area, vehicle parking and some supporting facilities at Sultan Hasanuddin International Airport. Observed sources of garbage; such as in the minimarket, restaurant, café 'area, employee room, public service area, check-in area, departure room, arrival room, and vehicle parking.

The following is a picture of the source and amount of waste generated at Sultan Hasanuddin-Makassar International Airport in several locations studied.

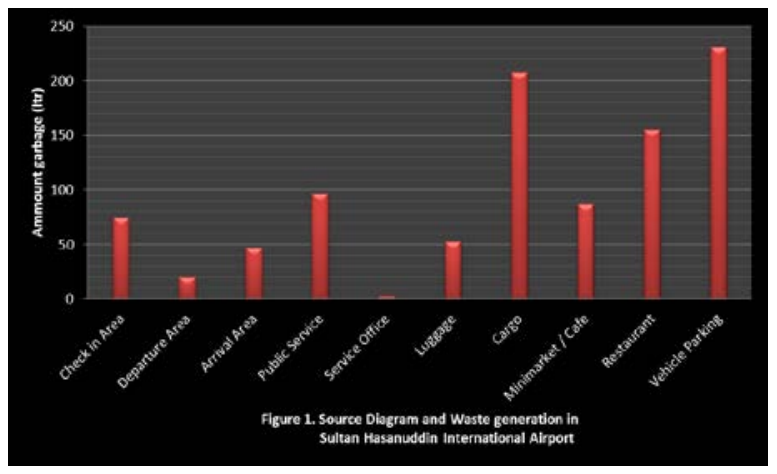

In figure 1 shows the amount of waste generated at the check in area as much $78.8 \mathrm{Itr}$, departure area $20.06 \mathrm{Itr}$, arrival area $46.8 \mathrm{Itr}$, publik service $96.6 \mathrm{Itr}$, service office $2.42 \mathrm{ltr}$, luaggage $52.4 \mathrm{ltr}$, cargo 208 Itr, minimarket/café $87.3 \mathrm{Itr}$ restaurant $155.3 \mathrm{Itr}$ and vehicle parking $231.4 \mathrm{Itr}$. 
Natsir Abduh; Sources and Management of Sustainable Waste. Case Study: Sultan Hasanuddin International Airport Makassar South Sulawesi Indonesia. Journal of Biomedical Engineering and Medical Imaging, Volume 5, No 6, December (2018), pp 10-17

\subsection{Waste Management System}

Waste management at Sultan Hasanuddin International Airport is currently implementing a system that is container-collecting-dumping. Disposal is carried out at the Temporary Disposal Site within the airport area, approximately 700 meters from the terminal building. In this place, the $3 R$ system is processed (Reuse, Reduce and Recycle) so that the waste is not all disposed of to the Final Disposal Site.

The following is described the waste management system and the amount of waste managed through the system.

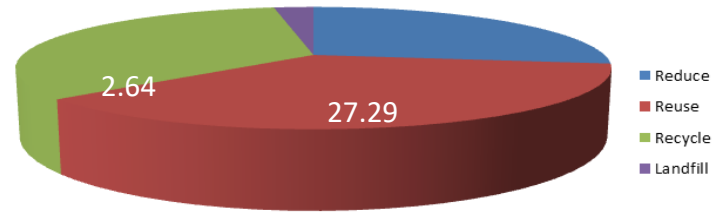

Source: Analysis results

Figure 2. Percentage of Waste Generation and Processing System

Based on the picture above, the amount of waste generated is 9,750 liters or $9.75 \mathrm{~m}^{3}$ every day. The amount of generation that can be recycled is $33.7 \%$, reduse is $27.29 \%$ and reuse is $36.37 \%$. The remaining $2.65 \%$ of waste that can be processed is transported to the Tabbangae Final Disposal Site in Maros Regency, South Sulawesi Province.

\section{Discussion}

\subsection{Passenger of Sultan Hasanuddin International Airport}

The results of the waste generation are due to human activities at the airport which every time increases along with the increasing number of passengers at Sultan Hasanuddin International Airport. This increase resulted in airport capacity not being met with plans to only accommodate 7 million passengers every year. Sultan Hasanuddin International Airport is included in the management of PT. Angkasa Pura I, which consists of several airports in Indonesia as shown in the map of the following airport locations.

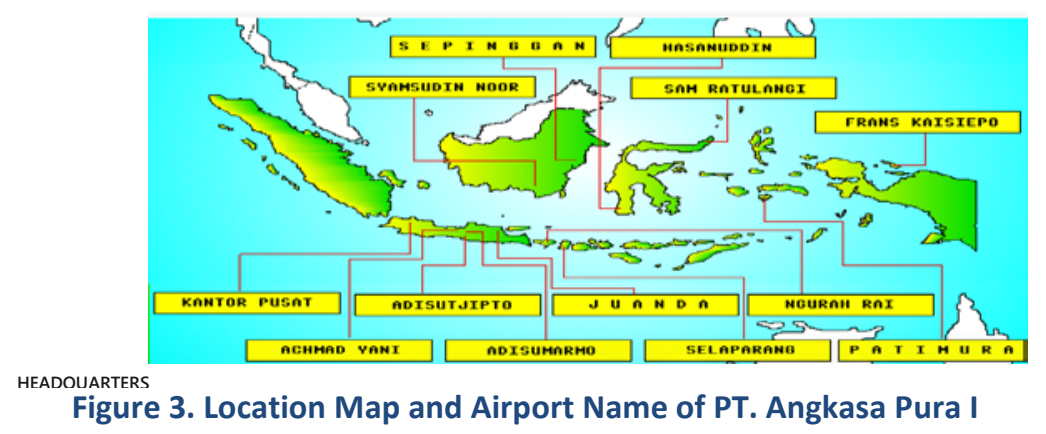

The number of passengers continues to increase along with the economic growth of South Sulawesi which is supported by economic development and development in the eastern region also starting to improve. The ability of the community to influence the use of aircraft as one of the transportation in the 
trip. The following is a graph of the increase in the number of passengers at Sultan Hasanuddin International Airport.

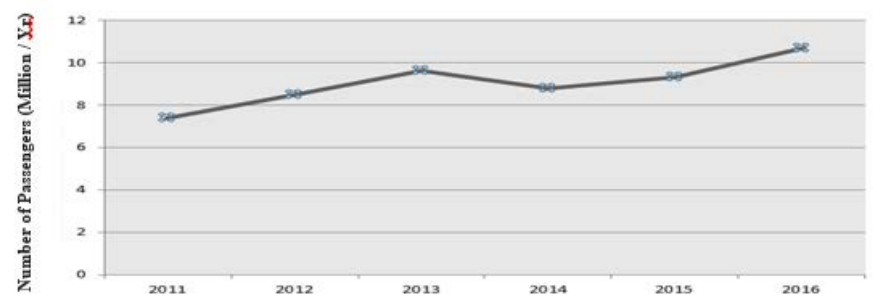

Figure 4. Graph of Increasing the Number of Passengers Sultan Hasanuddin International Airport

The overcapacity condition began to occur in 2011 with a total passenger number of 7.4 million people, in 2012 there were 8.5 million people, while in 2013 there were 9.6 million people. In 2014 there was a decline in passenger traffic but it was still above the existing capacity of the airport terminal, which is 8.8 million people. Then it experienced aggressive growth in 2015 to 9.3 million people and in 2016 it increased to 10.68 million people (Angkasa Pura I, PT. 2010).

The results of the analysis show that the increase from 2011 to 2013 was around 12.9\%. This development is estimated that by 2020 passengers will reach 15.08 million people.

\subsection{Sources and Characteristics of Waste}

\subsubsection{Waste Source}

Judging from the source, the garbage at Sultan Hasanuddin International Airport can be divided into:

a. Garbage Terminal Building

The source of garbage in the terminal building is food scraps and the most sourced from restaurants and cafés. Besides that there are also plastic, paper and cans.

b. Garbage Vehicle Parking

The source of garbage in the parking lot of the vehicle comes from plants in the parking lot of the vehicle in the form of wood and leaves. There are even restaurants that can cause garbage in the form of plastic and paper.

c. Waste Cargo

This cargo waste can be in the form of food scraps, plastic, paper and cans.

d. Aircraft Hangover Garbage

Hangar waste due to maintenance or repair of aircraft. A lot of garbage is used oil.

\subsubsection{Characteristics of Waste}

Garbage comes from the terminal building area, vehicle parking and some supporting facilities at Sultan Hasanuddin International Airport. Several sources of waste are observed; such as in the minimarket, restaurant, café 'area, employee room, counters, check-in area, departure room, arrival hall, vehicle and cargo parking.

The characteristics of waste are needed to plan waste management, for example equipment used, pattern of collection, methods of destruction and so on (Gultom, Osmen. 2002). To find out the 
Natsir Abduh; Sources and Management of Sustainable Waste. Case Study: Sultan Hasanuddin International Airport Makassar South Sulawesi Indonesia. Journal of Biomedical Engineering and Medical Imaging, Volume 5, No 6, December (2018), pp 10-17

characteristics of waste, research is needed both in the field and in the laboratory. Among the characteristics of waste that need to be known are (Alex S. 2012):

a. Garbage

Food waste comes from animals, vegetables and fruits come from management activities, preparation, cooking and leftovers.

Its main characteristics are humid, high water content, easily decomposed especially in areas such as Indonesia which have hot climates where weathering occurs faster.

The source of garbage is mainly from restaurants, cafés and employees who bring food from home.

b. Rubbish

The characteristics of this garbage are not easy to rot and are divided into two groups, namely:

- can be combustible for example; paper, cardboard, plastic, rubber, textile, wood and leather.

- non combustible for example; glass, cans, alumium, metal and dust.

c. Special waste

Solid waste generated from road sweeping activities, or drain cleaning. In the form of animal carcasses, paper, plastic, plants and cans.

There are characteristics of this garbage that are easily burned and destroyed and some are difficult to recycle.

\subsubsection{Waste Management}

Waste management can be carried out through a number of systems or methods, but what is simple and easy to do is implementing the 3R system; namely Reduce, Reuse and Recycle. This system is usually garbage can not be managed as a whole because it is influenced by the characteristics of the waste, so that the approach and equipment used must be appropriate (Yuni Puspitawati, Mardwi R, 2012).

\section{a. Reduce}

The reduce method is applied at Sultan Hasanuddin International Airport through providing education to the airport community on how to reduce the use of goods or objects that are not really needed. This information is carried out by containing:

- Reduce the use of plastic bags once used and then discard. Plastic bags are rubbish that need hundreds of years (200-300 years) to decompose.

- Prioritizing buying a container product, so it can be refilled.

- Repair damaged items (if they can be repaired).

- Reducing the use of disposable ingredients.

The results of the analysis showed that the waste processed through the reduse method amounted to $27.29 \%$ derived from plastic and tin waste.

\section{b. Reuse}

This method is carried out through the use and reuse of unused items into something new. This method is carried out by workers from the community who live around Sultan Hasanuddin International Airport.

This garbage is in the form of; used newspapers, cardboard boxes, milk cans, soap containers. These items can be utilized as best as possible.

- Say used goods become goods that can be reused.

- Reusing plastic bags shopping for the next shopping.

The results of the analysis showed that the waste processed through the reuse method was $36.37 \%$ which came from paper and fabric waste.

\section{c. Recycle}

Recycle used goods into items that can be reused through Insenerator tools.

- Organic waste can be used as fertilizer. 
- Inorganic waste can be recycled into something that can be reused. The material is in the form of; paper, plastic bottles.

The results of the analysis showed that the waste processed through the recycle method was $33.7 \%$, which came from leftovers, leftovers and wood. The results of this recycle are used as compost.

Development of alternative management methods with Insenerator tools, in order to optimize the process of managing waste produced, so as to reduce the volume of waste entering the Final Disposal Site Processing waste against waste that can be recycled to produce efficient and effective management.

If recycle is done, the use of a portion of the waste from processing results can be reused, so that airport operating costs can be reduced. The volume of waste to be transported to the Final Disposal Site (TPA) is reduced, so that the costs of mobilizing waste will also be reduced. The following is a picture of the percentage diagram of the generation and waste treatment system at Sultan Hasanuddin International Airport.

The results are from 9,750 liters or $9.75 \mathrm{m75}$ every day. The amount of generation that can be recycled is $33.7 \%$, reduse is $27.29 \%$ and reuse is $36.37 \%$. The remaining $2.65 \%$ of waste Final Disposal Site in Maros Regency, South Sulawesi Province.

\section{Conclutions}

1. The results of waste generation from the ten samples observed were found to be solid waste at; check in area $74.8 \mathrm{Itr}$, departure area $20.06 \mathrm{Itr}$, arrival area $46.8 \mathrm{Itr}$, public service $96.6 \mathrm{ltr}$, service office $2.42 \mathrm{ltr}$, luaggage $52.4 \mathrm{ltr}$, cargo $208 \mathrm{ltr}$, minimarket / café $87.3 \mathrm{ltr}$, restaurant $155.3 \mathrm{ltr}$ and vehicle parking $231.4 \mathrm{Itr}$. The highest amount of garbage in vehicle parking is $231.4 \mathrm{Itr}$ and at least in the service office as much as $2.42 \mathrm{Itr}$.

2. The waste management system is carried out through the 3R (Reduce, Reuse, Recycle) method and the rest is discharged to the Waste Disposal Site in Tabangae area, Maros Regency, South Sulawesi Province. Waste management through the Reduce system is $27.29 \%$, Reuse is $36.37 \%$, Recycle as much as $33.7 \%$ and the remaining $2.64 \%$ of waste is disposed to landfills.

\section{REFERENCES}

[1] Angkasa Pura I, PT. 2010. Data concerning Airports, Transportation Journal Vol.11 No.3, December 2011: 183-190.

[2] Alex S. 2012. Success in Processing Organic Waste into Organic Fertilizers. Yogyakarta: New Library Press.

[3] Arief M, 2014. Quality of Public Services at Sultan Hasanuddin International Airport Makassar, Hasanuddin University Journal.

[4] Adisasmita Sakti Adji and Josef Hadipramana, 2011. Improving The Airport Operation and Environmental Quality at Small Airports in Indonesia. Civil Engineering Department, Faculty of Engineering, University of Hasanuddin, Makassar, Indonesia.

[5] Chandra, Budiman. 2007. Introduction to Environmental Health. Jakarta: Publisher. Medical Book. 
Natsir Abduh; Sources and Management of Sustainable Waste. Case Study: Sultan Hasanuddin International Airport Makassar South Sulawesi Indonesia. Journal of Biomedical Engineering and Medical Imaging, Volume 5, No 6, December (2018), pp 10-17

[6] Dalay-Calayton and Bass, 2002. Sustainable Development Strategies. Jakarta Press.

[7] Danisworo, M, 1998. Paper Management of the quality of the environment and urban landscape in Indonesia in the face of the dynamics of the XXI century.

[8] Daryanto, 2004. Pollution Problems. Bandung: TARSITO.

[9] Dorodjatun, K., 2011. Sustainable Development: Implementation Past, Current and Future Into. Spatial Bulletin, National Spatial Planning Coordinating Agency, (2011 Edn), July-August (2011).

[10] Gultom, Osmen. 2002. Integrated Management of Urban Solid Waste. Center for Development of Radioactive Waste Management, Batam.

[11] Decree of the Minister of Transportation No. 44 of 2002. About the National Airport Order.

[12] Leony Yermina, Mery Selintung and Rahim, 2014. Study of Waste Management in Sultan Hasanuddin Airport, Hasanuddin University Journal.

[13] Natsir Abduh, 2015. Evaluation of Environmental and Socio-Cultural Dimension of Sustainability Eco-Airport International Airport Sultan Hasanuddin. Jurnal Environmental Volume: 95 (2015) issue No.3 (2015) Page:703-713.

[14] Natsir Abduh, 2016. Development of Environmentally Friendly Airports and Educational Facilities (Case Study: Sultan Hasanuddin International Airport). Dissertation of Doctoral Program of Makassar State University, 2016.

[15] Natsir Abduh, 2016. Environmental sustainability: the case of the Sultan Hasanuddin International Airport, Makassar South Sulawesi. Jurnal World Transactions on Engineering and Technology Education, Volume 14, No.3, 2016.

[16] Pranata, Dedy, 2014. Study of Alternative Domestic Waste Processing in Sultan Hasanuddin Airport. Thesis at Hasanuddin University.

[17] Salipadang, Joseph Crhistian, 2011. Analysis of the Waste Transportation System of Makassar City with Completion Method of Vehicle Routing Problem (VRP) (Case Study: Mamajang District). Makassar: Thesis at Hasanuddin University.

[18] Yuni Puspitawati, Mardwi R, 2012. Study of Community Based Waste Management with the $3 R$ Concept (Reduce, Reuse, Recycle) in the Larangan City of Cirebon Village. Journal of Regional and City Development, Volume 8 (4) 349-359 December 2012. 